\title{
DETERMINATION OF HYDROXYZINE BY DIFFERENTIAL PULSE ANODIC VOLTAMMETRY USING CARBON PASTE ELECTRODE
}

\author{
SAYED. I. M. ZAYED ${ }^{1,2}, A M A L$. A. H. AL-TALHI ${ }^{1}, A N D$ ASMAA, E. AL THAGAFI ${ }^{1}$ \\ ${ }^{I}$ Chemistry Department, Faculty of Science, Taif University, 888-Taif, KSA \\ ${ }^{2}$ Faculty of Industrial Education, Beni-Suef University, Beni-Suef, Egypt
}

\begin{abstract}
The electrochemical oxidation of hydroxyzine dihydrochloride at carbon paste electrode has been studied in $0.04 \mathrm{M}$ Britton-Robinson buffer $\mathrm{pH} 6.2 \mathrm{using}$ cyclic and differential pulse voltammetry. The oxidation process has been shown to irreversible and diffusion controlled with adsorption characterstics. Based on these studies, simple, rapid, and sensitive differential pulse anodic voltammetric method has been developed for the determination of the drug over the concentration range $0.45-5.36 \mu \mathrm{g} / \mathrm{ml}$, with detection and quantification limits of 0.27 and $0.90 \mu \mathrm{g} / \mathrm{ml}$ hydroxyzine dihydrochloride, respectively. The proposed method was successfully used for quantification of hydroxyzine dihydrochloride in Atarax tablets and spiked human urine.
\end{abstract}

Keywords: Hydroxyzine dihydrochloride, differential pulse anoding voltammetry, carbon paste electrodes, pharmaceutical dosage form, human urine.

\section{INTRODUCTION}

Hydroxyzine dihydrochloride, (RS)-2-\{2-[4-(p-Chloro-a-phenylbenzyl) piperazin-1-yl] ethoxy\} ethanol dihydrochloride [2192-20-3] (Scheme 1). It is antihistaminic drug which has several pharmacological effects, sedation, relaxation of muscles, and hypnotic properties. It is mainly used to reduce anxiety and tension for skeletal muscular relaxation or as an antiemetic drug. Its antispasmodic effect is probably due to its interference with the mechanism that responds to spasmogenic agents such as serotonin, acetylcholine, and histamines.<smiles>OCCOCCN1CCN(C(c2ccccc2)c2ccc(Cl)cc2)CC1</smiles>

Scheme 1. Structural formula of hydroxyzine dihydrochloride.

Several analytical methods have been reported for the determination of hydroxyzine, including, high performance liquid chromatography (HPLC), ${ }^{2-11}$ gas chromatography (GC), ${ }^{12}$ thin-layer chromatography, ${ }^{13}$ spectrophotometry, ${ }^{14-17}$ capillary electrophoresis, ${ }^{18}$ potentiometry, ${ }^{19-21}$ and conductimetric titration. ${ }^{22}$ Also two voltammetric methods have been reported for determination of the drug based on oxidation of the drug on glassy carbon or modified glassy carbon electrodes. ${ }^{23,24}$ Carbon paste electrodes are widely used applicable in electrochemical studies due to their low background current compared to solid graphite or noble metals electrodes, low cost, easy preparation, and simple renewal of their surfaces. The present work aimed to study of the voltammetric behavior and assay of hydroxyzine dihydrochloride at carbon paste electrode using cyclic and differential pulse voltammetry.

\section{EXPERIMENTAL}

Reagents and materials

All chemicals were of analytical grade. Double distilled water was used throughout all experiments,. Pure grade hydroxyzine dihydrochloride, and the pharmaceutical preparation, Atarax tablets (10 mg hydroxyzine dihydrochloride/ tablet) were kindly supplied by Chemical Industries Development CID, Giza, Egypt. graphite powder (1-2 micron) from Aldrich. and paraffin oil from BDH. As a supporting electrolyte, a series of $0.04 \mathrm{M}$ Britton-Robinson (BR) buffer pH 2.0-11.5 (a mixture of each of acetic, orthophosphoric and boric acids), adjusted to the required $\mathrm{pH}$ with $0.2 \mathrm{M}$ sodium hydroxide was prepared.
Apparatus

All voltammetric measurements were performed using Metrohm 797 VA Computrace (Herisau, Switzerland) equipped with a Metrohm VA 694 stand. The three electrodes assembly cell consisted of carbon paste electrode (CPE) as working electrode, an $\mathrm{Ag} / \mathrm{AgCl}$ in $3 \mathrm{~mol} / \mathrm{L} \mathrm{KCl}$ as a reference electrode, and platinium wire as an auxiliary electrode. The $\mathrm{pH}$ measurements were carried out using Hanna pH 211 microprocessor $\mathrm{pH}$ meter.

\section{Preparation of carbon paste electrodes}

The carbon paste was prepared by hand mixing of $5 \mathrm{~g}$ of graphite powder with $1.8 \mathrm{ml}$ of paraffin oil in a mortar with pestle. The resulting carbon paste was tightly packed into the hole of the electrode body and smoothed on a clean paper until it had a shiny appearance. The electrode body was constructed by pressing a small rod of stainless steel (diameter $2 \mathrm{~mm}$ ) inside a micropipette tip ( $1 \mathrm{ml}$ volume capacity), leaving a depression at the tip surface of approximately $1 \mathrm{~mm}$ for housing the carbon paste, and a thin wire was inserted through the opposite end for electrical contact. ${ }^{25}$ The prepared carbon paste electrode was immersed in the supporting electrolyte in the cell, and applying sweeps to obtain a low background current.

General procedure

A $10 \mathrm{ml} 0.04 \mathrm{M}$ BR buffer solution $\mathrm{pH} 6.2$ was introduced into a clean and dry voltammetric cell, and the required amount of the drug was added to the cell, The differential pulse technique was applied by scanning from 0 to $1.4 \mathrm{~V}$, with scan rate of $50 \mathrm{mVs}^{-1}$, and pulse amplitude of $50 \mathrm{mV}$. ablets

Procedure for determination of hydroxyzine dihydrochloride in Atarax

Twenty tablets were weighed, and the average mass per tablet was determined, then these tablets were powdered in a mortar. The required amount from the crushed tablet powder was dissolved in about $30 \mathrm{ml}$ of bidistilled water and filtered in a $50 \mathrm{ml}$ measuring flask. The residue was washed three times with bidistilled water; the volume was completed to the mark by the same solvent. After $10 \mathrm{ml}$ volume of $0.04 \mathrm{M}$ BR buffer solution $\mathrm{pH} 6.20$ was introduced into the voltammetric cell, and a known amount of the tablet solution was added into the cell; the procedure is repeated as described above. The amount of hydroxyzine dihydrochloride is calculated using standard addition technique.

Determination of hydroxyzine dihydrochloride in spiked human urine

$0.0448 \mathrm{~g}$ of hydroxyzine dihydrochloride was dissolved in bidistilled water and transferred to $100 \mathrm{ml}$ measuring flask; $5 \mathrm{ml}$ urine of a healthy person was added, and the mixture was completed to the mark by the same solvent to prepare $10^{-3} \mathrm{M}$ hydroxyzine dihydrochloride in spiked urine sample. A $10 \mathrm{~m}$ of $0.04 \mathrm{M}$ BR buffer solution $\mathrm{pH} 6.20$ was introduced into the voltammetric cell; different volumes of the above spiked urine sample were added into the cell; the procedure is repeated as described above. The amount of hydroxyzine dihydrochloride is calculated using standard addition technique. 


\section{RESULTS AND DISCUSSION}

Cyclic voltammetric studies

Cyclic voltammetric technique was applied as a diagnostic tool to get information about the electrochemical behavior of hydroxyzine dihydrochloride at carbon paste electrode. Fig. 1 shows the cyclic voltammograms for $1.96 \mathrm{x}$ $10^{-5} \mathrm{M}$ hydroxyzine dihydrochloride in $0.04 \mathrm{M} \mathrm{BR}$ buffer solution $\mathrm{pH} 6.2$, at scan rate of $50 \mathrm{mVs}^{-1}$ after accumulation time of $30 \mathrm{~s}$.

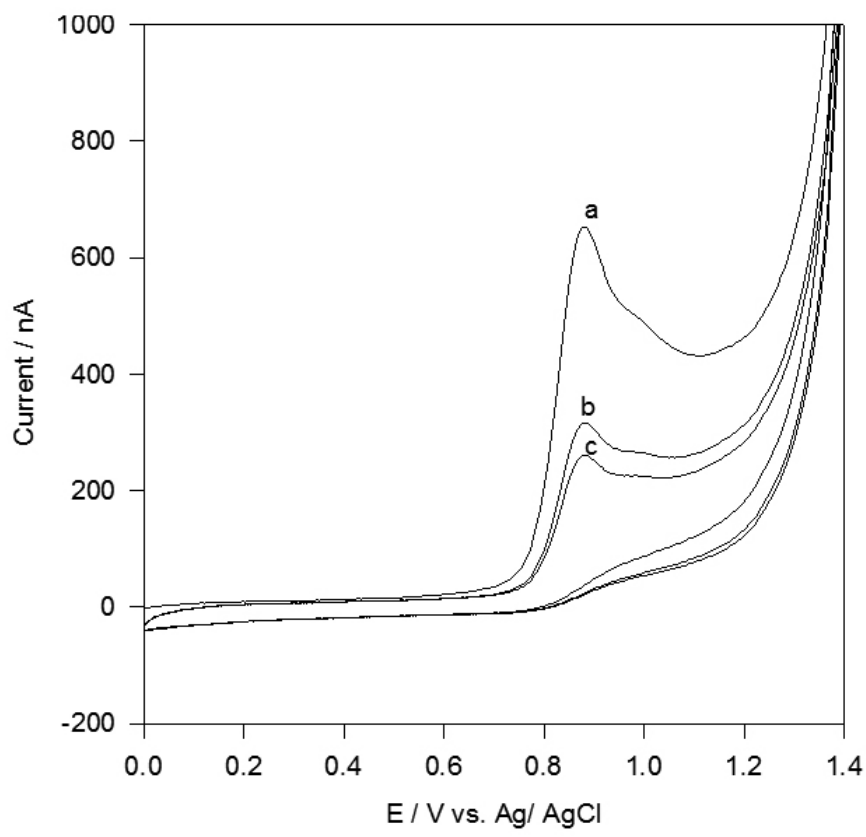

Figure 1. Successive cyclic voltammograms of $1.96 \times 10^{-5} \mathrm{M}$ hydroxyzine dihydrochloride solution in $0.04 \mathrm{M}$ Britton-Robinson $\mathrm{pH} 6.20$ and scan rate of $50 \mathrm{mVs}^{-1}$ after an accumulation of $30 \mathrm{~s}$.

A well defined anodic peak at $0.873 \mathrm{~V}$, which may be attributed to the oxidation of the hydroxyl group of the aliphatic chain moiety of the analyte molecule. ${ }^{23}$ On reverse scanning no cathodic peak was observed, confirming the irreversible nature of the process. The repetitive cyclic voltammograms show that the peak current decreases in the second and third cycles, and this behavior gives an indication of an adsorption character. A plot of logarithm of peak current versus logarithm of the scan rate within the range $10-100 \mathrm{mVs}^{-1}$, gave a straight line relation with a slope of 0.71 which is intermediate value between 0.5 and 1.0 , suggested a mixed diffusion-adsorption oxidation process.

Differential pulse (DP) voltammetric studies

Various supporting electrolytes such as sodium perchlorate, phosphate buffer, citrate buffer, and Britton-Robinson buffer, were examined. The best results with respect to signal enhancement and peak shape was obtained with Britton-Robinson buffer, so this buffer was chosen for the subsequent experiments. The effect of $\mathrm{pH}$ on the peak current and oxidation potential were studied over the $\mathrm{pH}$ range 3.0-10.0 (figure 2).

The peak current gradually increases with increase of $\mathrm{pH}$ and reached a maximum value when the $\mathrm{pH}$ is 6.2 , then further increase in the solution $\mathrm{pH}$ yield a decrease in current. A negative shift was observed in the oxidation peak potential with increase of $\mathrm{pH}$ suggesting involvement of protons in the electrode reaction process

The effect of accumulation potential $\mathrm{E}_{\mathrm{a}}$ on the peak current was studied for $2 \times 10^{-6} \mathrm{M}$ hydroxyzine dihydrochloride at $30 \mathrm{~s}$ accumulation time, $50 \mathrm{mVs}^{-1}$ scan rate, and $50 \mathrm{mV}$ pulse amplitude, the peak current was nearly constant on changing the accumulation potential $\mathrm{E}_{\mathrm{a}}$ from 0 to $700 \mathrm{mV}$.

The effect of accumulation time $t$ on the peak current was studied for two concentration level $5 \times 10^{-7}$ and $2 \times 10^{-6} \mathrm{M}$ hydroxyzine dihydrochloride (Figure $3)$.

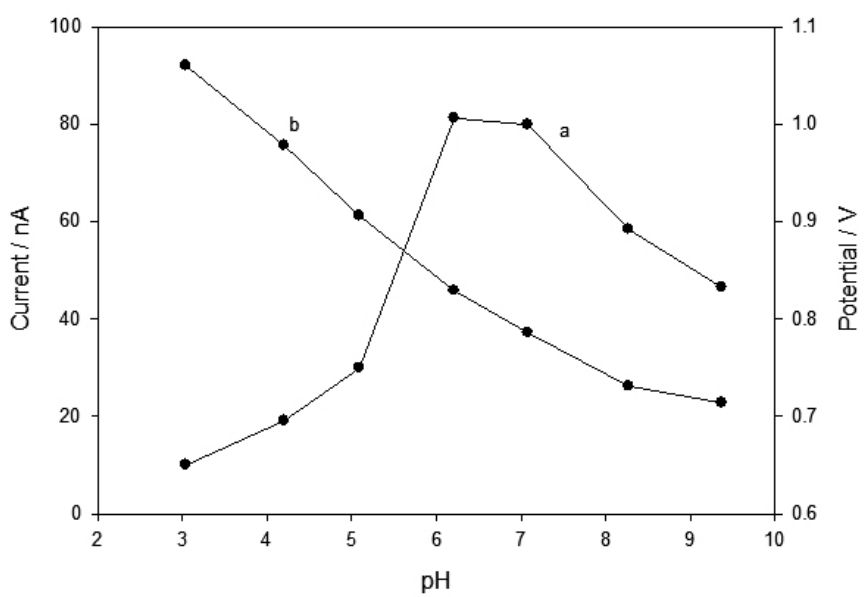

Figure 2. Effect of $\mathrm{pH}$ on the DP anodic peak current (a), and peak potential (b) of $2 \times 10^{-6} \mathrm{M}$ hydroxyzine dihydrochloride in $0.04 \mathrm{M}$ BR buffer, scan rate $50 \mathrm{mVs}^{-1}$, and pulse amplitude of $50 \mathrm{mV}$.

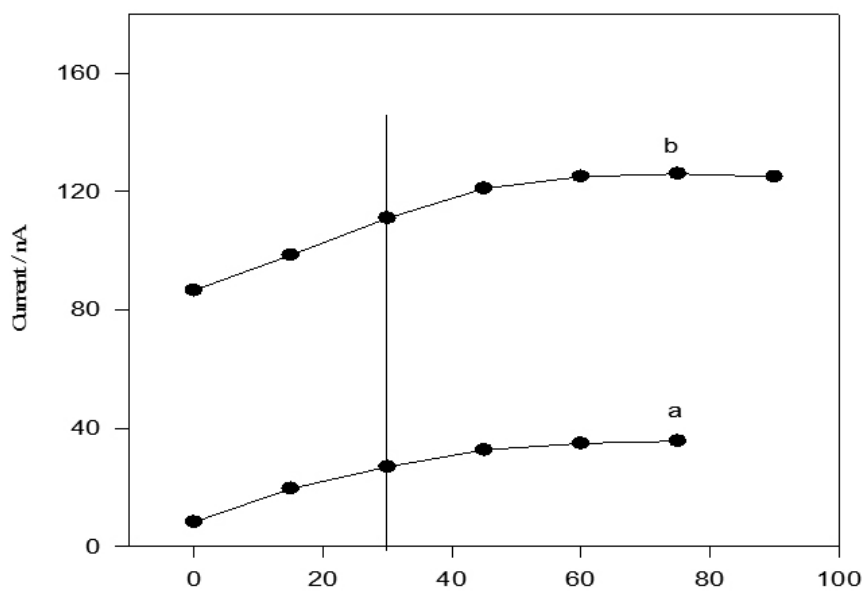

Figure 3. Effect of accumulation time $\left(\mathrm{t}_{\mathrm{a}}\right)$ on the peak current for $5 \times 10^{-7}$ and $2 \times 10^{-6} \mathrm{M}$ hydroxyzine dihydrochloride in $0.04 \mathrm{M}$ BR buffer $\mathrm{pH} 6.20$, accumulation potential $\left(\mathrm{E}_{\mathrm{a}}=0\right)$, scan rate $=50 \mathrm{mVs}^{-1}$, and pulse amplitude $50 \mathrm{mV}$.

The current increases linearly with increasing the accumulation time $\mathrm{t}_{\mathrm{a}}$ indicating that the longer the accumulation time, the increase the drug concentration in the electrode surface, and the larger the peak current, then as the accumulation time increases the peak current tends to level off. $30 \mathrm{~s}$ accumulation time was used for subsequent studies.

The optimum instrumental parameters were chosen through the study of the variation of peak current of $2.0 \times 10^{-6} \mathrm{M}$ hydroxyzine dihydrochloride with change of pulse amplitude and scan rate, the results indicate that the current increases with increase of pulse amplitude over the range $10-50 \mathrm{mV}$, then remains nearly constant. The peak current also increased with increase of scan rate over the range $10-50 \mathrm{mVs}^{-1}$, so $50 \mathrm{mV}$ pulse amplitude, and $50 \mathrm{mVs}^{-1}$ scan rate were selected for further work.

Calibration graph, limit of detection and limit of quantification

Under the optimized conditions of accumulation potential of 0 volt, accumulation time $30 \mathrm{~s}$, scan rate $50 \mathrm{mVs}^{-1}$, and $50 \mathrm{mV}$ pulse amplitude, the peak current of differential pulse voltammograms was found to be linearly related to the hydroxyzine dihydrochloride concentration in the linear range $0.45-5.36 \mu \mathrm{g} / \mathrm{ml}$ (Figure 4). The linear regression equation was I (nA) = $-16.69+159.36 \mathrm{C}(\mu \mathrm{g} / \mathrm{ml})$, with correlation coefficient of 0.9981 . Limit of detection (LOD), and limit of quantification (LOQ), were calculated using the relation $\left(\mathrm{k}\left(\mathrm{SD}_{\mathrm{a}}\right) / \mathrm{b}\right),{ }^{26}$ where $\mathrm{k}=3$ for $\mathrm{LOD}$, and 10 for $\mathrm{LOQ}, \mathrm{SD}_{\mathrm{a}}$ is the standard deviation of the intercept, and $\mathrm{b}$ is the slope of the calibration curve, were found to be 0.27 and $0.90 \mu \mathrm{g} / \mathrm{ml}$ for LOD and LOQ, respectively. The analytical parameters of the calibration curve are summarized in Table 1. 


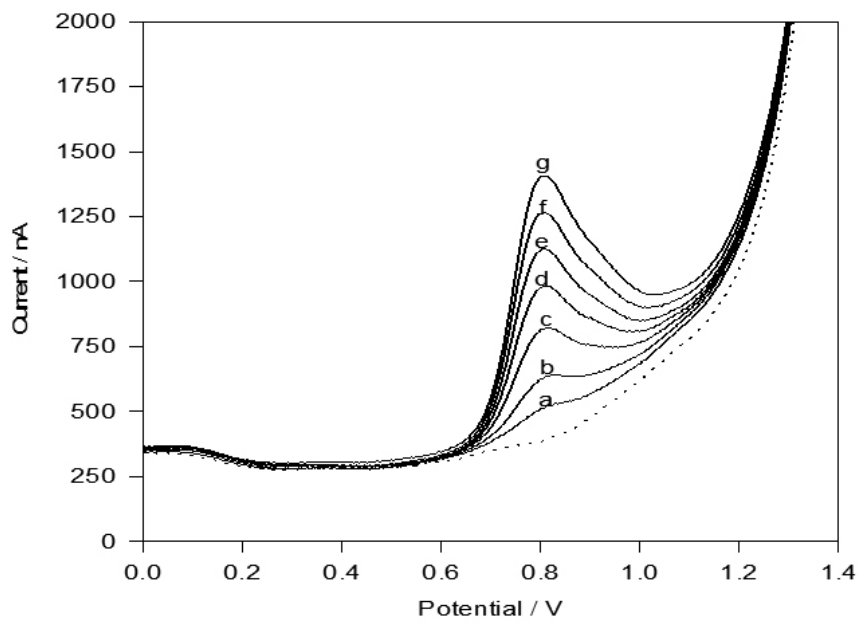

Figure 4. Differential pulse voltammograms for different concentration of hydroxyzine dihydrochloride in $0.04 \mathrm{M}$ Britton-Robinson buffer $\mathrm{pH} 6.2$, scan rate of $50 \mathrm{mVs}^{-1}$ and pulse amplitude of $50 \mathrm{mV}$ : a, $0.45 ; \mathrm{b}, 0.89 ; \mathrm{c}, 1.79 ; \mathrm{d}, 2.68$ e, $3.58 ; \mathrm{f}, 4.47$; and $\mathrm{g}, 5.36 \mu \mathrm{g} / \mathrm{ml}$ hydroxyzine dihydrochloride.

The dotted line represents the blank solution.

Table 1. The analytical parameters of the calibration graph for the determination of hydroxyzine dihydrochloride by differential pulse anodic voltammetric method.

\begin{tabular}{|c|c|}
\hline Parameter & \\
\hline Linear range, $\mu \mathrm{g} / \mathrm{ml}$ & $0.45-5.36$ \\
Slope & 159.36 \\
Intercept & -16.69 \\
Correlation coefficient (r) & 0.9981 \\
LOD, $\mu \mathrm{g} / \mathrm{ml}$ & 0.27 \\
LOQ, $\mu \mathrm{g} / \mathrm{ml}$ & 0.90 \\
\hline
\end{tabular}

Reproducibility and robustness

The intra-day and inter-day (day-to-day) precision, were examined by analysis of $2 \times 10^{-6} \mathrm{M}$ hydroxyzine dihydrochloride wih 8 replicates in the same day or three consecutive days. The RSD value for intra-day and the inter-day precision were $0.93 \%$ and $4.98 \%$, respectively. The robustness ${ }^{26}$ of the proposed method was tested by evaluating the effect of small change in some of the most important procedure parameters, including $\mathrm{pH}$ (6.0-6.4), accumulation time $(28-32 \mathrm{~s})$, and pulse amplitude $(48-52 \mathrm{mV})$. The results showed that none of the changes significantly affect the recovery of the drug (Table 2), and consequently the optimized procedure was reliable for the assay of the drug, and it could be considered robust.

\section{Interferences}

In order to prove the selectivity of the proposed voltammetric method, interference from excipients usually present in pharmaceutical formulations was tested. The results indicate that no interference $(<4.2 \%$ change in the oxidation current), was observed in the presence of 100 fold excess of lactose, talc, maize starch or magnesium stearate. The results indicate that the proposed voltammetric method is sufficiently selective and no previous separations or extractions were needed.

\section{Analytical application}

The proposed differential pulse anodic voltammetric method was successfully applied for the assay of hydroxyzine dihydrochloride in the pharmaceutical formulation Atarax tablets (10 mg hydroxyzine dihydrochloride /tablet). The percentage mean recovery based on the average of four replicate determinations and the relative standard deviation values are summarized in Table 3. The results indicate that there is no interference from the excipients used in the formulations of the tablets. The results of the proposed method were compared with the results obtained by analysis of the tablets by using the HPLC official method of United States USP pharmacopeia. ${ }^{27}$ The results are in good agreement with the nominal value and with the average recovery obtained from the official method. Statistical comparison of the accuracy and precision of the proposed voltammetric method with the official method was performed using Student's t-test and the Fisher-Snedecor (F-test) at a 95\% confidence level. ${ }^{28}$ The t- and F- values did not exceed the theoretical values; there is no significant difference in accuracy or precision between the proposed voltammetric and the official methods.

Table 2. Robustness results of the proposed method at the optimum parameters.

\begin{tabular}{|r|cc|}
\hline Variable & Recovery, $\%$ & SD, $\%$ \\
\hline $\mathrm{pH}=6.0$ & 98.99 & 1.667 \\
6.2 & 97.56 & 1.543 \\
6.4 & 102.55 & 1.969 \\
& & \\
Pulse ampltude & 99.56 & 0.937 \\
$=48$ & 97.56 & 1.543 \\
50 & 98.93 & 1.158 \\
52 & & \\
& & \\
Accumulation time & 100.00 & 0.606 \\
$=28$ & 97.56 & 1.543 \\
30 & 100.60 & 1.081 \\
32 & &
\end{tabular}

Average of four determinations

Table 3. Statistical comparison between the results of Atarax tablets using the proposed DP voltammetric method and the official HPLC method.

\begin{tabular}{|c|cc|}
\hline Parameters & Proposed DP voltammetric & $\begin{array}{c}\text { Official HPLC } \\
\text { Method }^{27}\end{array}$ \\
\hline Mean recovery, \% & 99.55 & 99.87 \\
SD & 1.46 & 0.50 \\
RSD, \% & 1.47 & 0.50 \\
F-ratio (9.12) & 8.526 & \\
t-test (2.365) & 0.232 & \\
\hline
\end{tabular}

Hydroxyzine may given orally as the hydrochloride or embonate, Absorption of hydroxyzine from the GI tract is rapid and complete, less $2 \%$ of the administered dose is recovered unchanged in feces and urine. ${ }^{29}$ The high selectivity of the proposed method allowed the determination of the drug in spiked human urine samples at two different levels of concentrations: $7.49 \times 10^{-7}$ and $1 \times 10^{-6} \mathrm{M}$ hydroxyzine dihydrochloride. Four determinations were carried at each concentration level (Table 4). The mean recoveries for the two concentration levels were 99.87 and $99.40 \%$, with relative standard deviations of $2.21 \%$ and $0.92 \%$, respectively.

Table 4 Determination of hydroxyzine dihydrochloride in spiked human urine samples using the proposed differential pulse anodic voltammetric method

\begin{tabular}{|l|lll|}
\hline Taken $(\mathrm{M})$ & Found (M) & Recovery, \% & RSD \\
\hline $7.49 \times 10^{-7}$ & $7.48 \times 10^{-7}$ & 99.87 & 2.21 \\
$1.00 \times 10^{-6}$ & $9.94 \times 10^{-7}$ & 99.40 & 0.92 \\
\hline
\end{tabular}

Average of four determinations.

\section{CONCLUSION}

In this work electrochemical oxidation of hydroxyzine dihydrochloride at carbon paste electrodes has been investigated using cyclic and differential pulse voltammetry. Differential pulse voltammetric procedure have been developed for the determination of this drug in its pharmaceutical formulation and spiked human urine. The developed method was a good alternative for the analytical determination of the drug, because it was, simple, rapid, low cost, and had sufficient precision, accuracy and sensitivity. 


\section{REFERENCES}

1. J. Tsau, and N. DeAngelis, Analytical Profiles of Drug Substances1978; vol. 7, 321 .

2. G. N. Menon, B. J. Norris, J. Pharm. Sci., 70, 697, (1981)

3. S. E. Roberts, M. F. Delaney, J. Chromatogr., 242, 364, (1982)

4. A. N. Papas, S. M. Marchese, F. Delaney, LC Magazine, 2, 120, (1984)

5. D. Boberic-Borojevic, D. Radulovic, D. Ivanovic, P. Ristic, J. Pharm. Biomed. Anal., 21, 15, (1999)

6. S. F. Hammad, M. M. Mabrouk, A. Habib, H. El Fatatry, N. Kishikawa, K. Nakashima, N. Kuroda, Biomed. Chromatogr., 21, 1030, (2007)

7. Z. Neng, L. Yi-Zeng, C. Ben-Mei, W. Ping, C. Xian, L. Feng-Ping, Chromatographia, 66, 481 (2007)

8. Z. Bikui, C. Benmei, Z. Yungui, L. Huande, M. Ning, L. Wu, F. Sheng, Yaowu Fenxi Zazhi, 28, 516, (2008)

9. A. F. B. Marcos, G. B. N. Luiz, C. P. Hudson, G. R. Fonseca, M. Gabriela, P. V. Urias, R. B. R. Nadia, N. G. Livia, O. F. Anderson, Latin American Journal of Pharmacy, 30, 1798 (2011)

10. R. Alswayeh, S. N. Alvi, M. M. Hammami, World journal of Pharmacy and Pharmaceutical Sciences, 4, 127 (2015)

11. N. Sher, F. A. Siddiqui, N. Fatima, S. Perveen, N. Shafi, J. Liq. Chromatogr. \& Rel Techn., 38, 911 (2015)

12. P. Kintz, B. Godelar, P. Mangin, Forensic Sci. Int., 48, 139, (1990)

13. H. Ackermann, F. Kretzschmann, S. Kruger, B. Lexow, Nahrung, 21, 603, (1977)

14. R. T. Sane, C. H. Thombare, P. G. Anaokar, A. D. Pandit, Indian Drugs, 18, 295, (1981)
15. N. Rajendraprasad, K. Basavaiah, K. B. Vinay, H. D. Revanasid dappa, J. Mex. Chem. Soc., 54, 233, (2010)

16. N. Rajendraprasad, K. Basavaiah, K. B. Vinay, J. Serb. Chem. Soc., 76, 1551, (2011)

17. A. Mumtaz, S. Hussain, M. Yasir, Pak. J. Pharm. Sci., 27, 1157, (2014)

18. Y. H. Ho, H. L. Wu, S. M. Wu, S. H. Chen, H. S. Kou, Anal. Bioanal. Chem., 376, 859, (2003)

19. A. Bouklouze, M. Elbourekraoui, Y. Cherrah, M. Hassar, J-M. Kauffmann, Electroanalysis, 14, 1369, (2002)

20. M. Javanbakht, S. E. Fard, A. Mohammadi, M. Abdouss, M. R. Ganjali, P. Norouzi, L. Safaraliee, Anal. Chimica Acta, 612, 65, (2008)

21. A. A. Wassel, Anal. Bioanal. Electrochem., 4, 17, (2012)

22. R. Mikulski, B. Dembinski, Anal. Chimica Acta, 272, 233, (1993)

23. A. M. Beltagi, O. M. Abdallah, M. M. Ghoneim, Talanta, 74, 851, (2008)

24. F. Huang, Y. Peng, G. Jin, S. Zhang, J. Kong, Sensors, 8, 1879, (2008)

25. A. Elyacoubi, S. I. M. Zayed, B. Blankert, J-M., Kauffmann, Electroanalysis, 18, 345, (2006)

26. M. Swartz, and I. S. Krull, Analytical Method Development and Validation, Marcel Dekker, Inc., 1997; 61.

27. The United States Pharmacopeia, 38, The National Formulary 33, United States Pharmacopeial Convention, 2015; 3815.

28. J. C. Miller, and J. N. Miller, Statistics for Analytical Chemistry, $3^{\text {rd }}$ ed., Ellis Horwood, Chichester, 1993; 53.

29. S. Kacew, Drug Toxicity \& Metabolism in Pediatrics, US CRC Press Inc., 1990; 257. 